\title{
СТАТИСТИКА
}

МРНТИ 06.35.33

УДК 311.14 https://doi.org/10.51579/1563-2415.2021-3.01

\section{О ПРЕДСТАВЛЕНИИ СТОИМОСТНЫХ СТАТИСТИЧЕСКИХ ДАННЫХ СТРАН ЕАЭС В ЕДИНОЙ ЭКОНОМИКО-СТАТИСТИЧЕСКОЙ СЧЕТНОЙ ЕДИНИЦЕ}

\author{
Ю.К. Шокаманов*, А.А. Демесинова \\ Академия государственного управления, Нур-Султан, Казахстан \\ e-mail: shokamanov53@mail.ru
}

Аннотация. В статье рассмотрена методология расчета и использования условной экономико-статистической счетной единицы (ЭССЕ) в целях анализа экономического развития Евразийского экономического союза (ЕАЭС), которая позволяет исключить влияние изменения курсов начиональных валют к доллару США на динамику данных стран ЕАЭС, представленных в долларах США.

На основе предложенной методики с использованием данных Евразийской экономической комиссии и Всемирного банка приведены результаты расчетов курсов и паритетов покупательной способности (ППС) национальных валют стран ЕАЭС и доллара США к ЭССЕ.

В предложенной условной ЭССЕ представлена и проанализирована динамика основных стоимостных показателей стран ЕАЭС за 2015-2020 годы, которая зависит только от изменения физических объемов и цен статистических показателей.

Проведено сравнение данных ВВП стран ЕАЭС в условной ЭССЕ, рассчитанных по курсам и ППС начиональных валют к ЭССЕ, на основе которого рассчитан показатель уровня цен в странах по отношению к среднему уровню цен в региональном объединении.

Рассчитаны ППС ЭССЕ к доллару США для ЕАЭС в челом и по странам ЕАЭС, которые аналогично странам еврозоны показали заметное различие по странам регионального объединения.

Ключевые слова: индексный анализ, общая валюта, условная экономикостатистическая счетная единица, паритет покупательной способности.

Основные положения. Динамика стоимостных показателей различных стран ЕАЭС, рассчитанных в долларах США с использованием курсов национальных валют к доллару США, включает в себя колебания курсов национальных валют к доллару США. Для их исключения предложено рассчитать средний индекс изменений курсов национальных валют к доллару США, взвешенных по ВВП стран региона в долларах США по ППС, и разделить на него эти стоимостные данные. Полученные результаты будут представлять данные в условной ЭССЕ.

Соотношение данных по ВВП в ЭССЕ и в долларах США для базисного года будет являться курсом ЭССЕ к доллару США в целом для регионального объединения. Курсы для последующих периодов рассчитываются путем умножения курса базисного года на средний индекс влияния изменения курсов национальных валют к доллару 


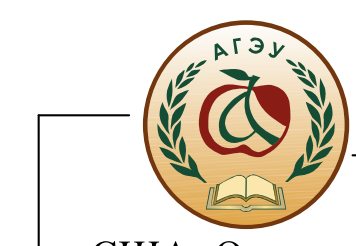

США. Отношение курсов национальных валют к доллару США к курсам ЭССЕ к доллару США будет представлять курсы национальных валют к ЭССЕ, с использованием которых можно перевести в единую счетную единицу данные регионального объединения.

Аналогично, разделив динамику данных стран ЕАЭС по ВВП в долларах США по ППС на средний индекс изменения ППС национальных валют к доллару США, можно представить ВВП в условной ЭССЕ по ППС. Соотношения ВВП стран ЕАЭС, представленных в ЭССЕ по курсам и по ППС ЭССЕ к доллару США, определяют уровни цен в странах относительно среднего уровня цен по региону.

Введение. Отсутствие в Евразийском экономическом союзе (ЕАЭС) единой валюты или расчетной единицы заставляет исследователей искать альтернативные способы анализа развития регионального объединения. Однако многие из них имеют свои недостатки. Так, представление данных стран ЕАЭС в российских рублях не учитывает роли других экономик регионального союза. Представление данных в долларах США по паритетам покупательной способности (ППС) национальных валют к доллару США включает в них динамику дефлятора ВВП США, но не включает ценовую динамику стоимостных показателей ЕАЭС.

В статистических публикациях Евразийской экономической комиссии все основные стоимостные показатели государств - членов ЕАЭС переводятся в доллары США с использованием курсов национальных валют к доллару США. Однако такое представление данных стран ЕАЭС имеет недостаток, заключающийся в том, что динамика этих показателей содержит в себе изменения, связанные не только с ростом объемов стоимостных показателей стран в текущих ценах, но и с изменениями курсов национальных валют к доллару США, которые в отдельные периоды времени являются основной причиной резкого снижения объемов стоимостных показателей в долларах США (рисунок 1).

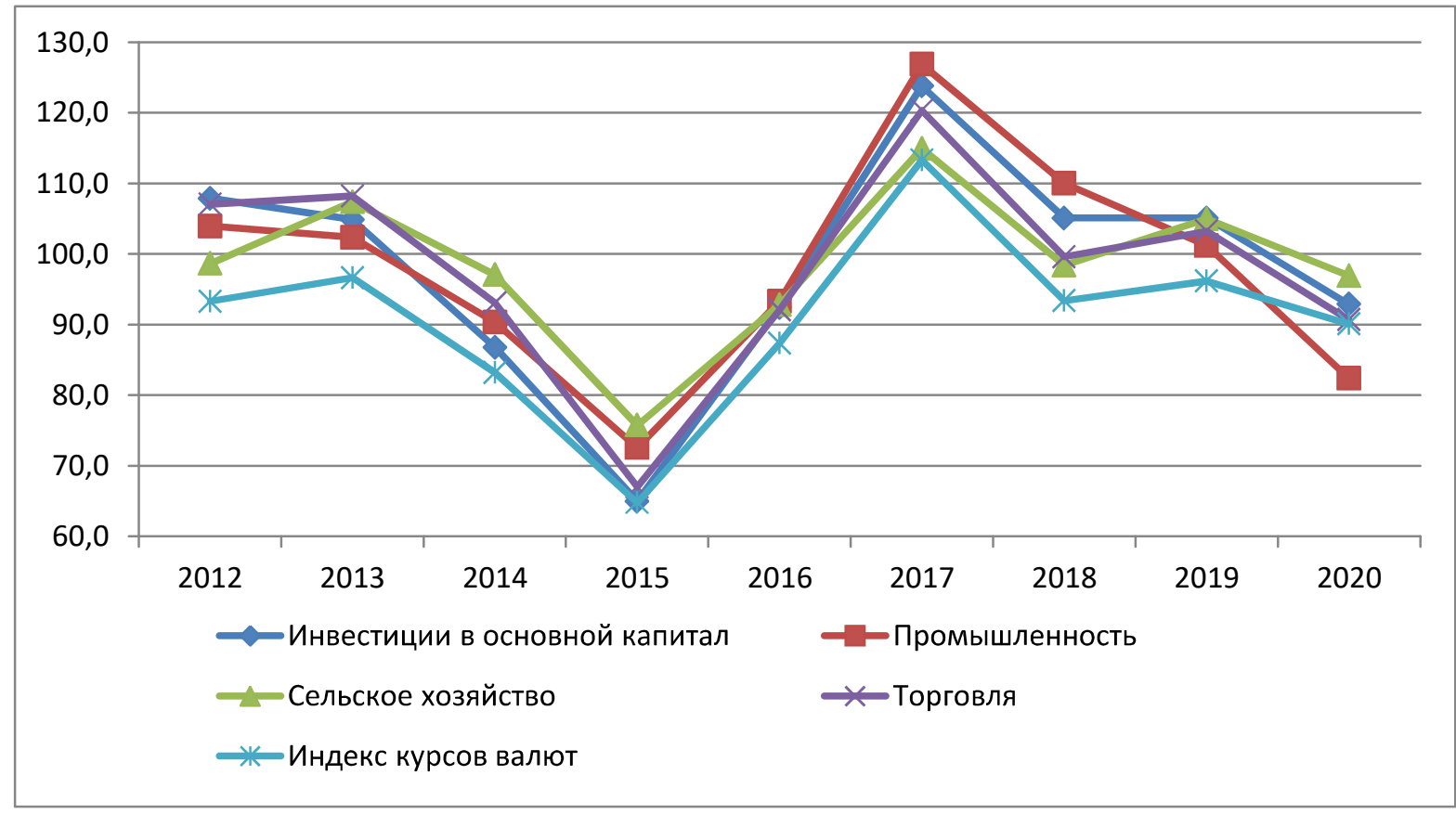

Рисунок 1 - Динамика отдельных показателей ЕАЭС в долларах США и индекса изменения курсов начиональных валют стран ЕАЭС к доллару США (прочентов) 
Нами был предложен свой вариант, заключающийся в представлении стоимостных статистических данных государств - членов ЕАЭС в некоторой единой условной экономико-статистической счетной единице (ЭССЕ), которая бы исключала изменение курсов национальных валют к доллару США. Такая счетная единица играла роль как бы единой расчетной единицы или общей валюты, как в свое время в Европейском Союзе использовалась единая расчетная единица ЭКЮ, а затем была введена общая валюта евро. Однако в отличие от Европейского Союза ее предлагается применять только для представления стоимостных статистических данных стран в единой счетной единище в целях анализа экономического развития стран ЕАЭС и объединения в целом.

Материалы и методы. Для исключения колебаний курсов национальных валют по отношению к доллару США в динамике стоимостных показателей стран ЕАЭС было предложено рассчитать средний индекс влияния изменения курсов национальных валют к доллару США на динамику данных стран ЕАЭС и объединению в целом, представленных в долларах США, и разделить на него эти данные, исключив тем самым влияние изменения курсов национальных валют. При этом данные в долларах США по объединению в целом для первого (базисного) года принимаются за данные в условной ЭССЕ, а данные в долларах США остальных периодов делятся на этот средний индекс изменения национальных валют стран ЕАЭС, что переводит их в данные, представленные в условной ЭССЕ. С учетом этого динамика показателей ЕАЭС, приведенная на рисунке 1 , представлена на рисунке 2.

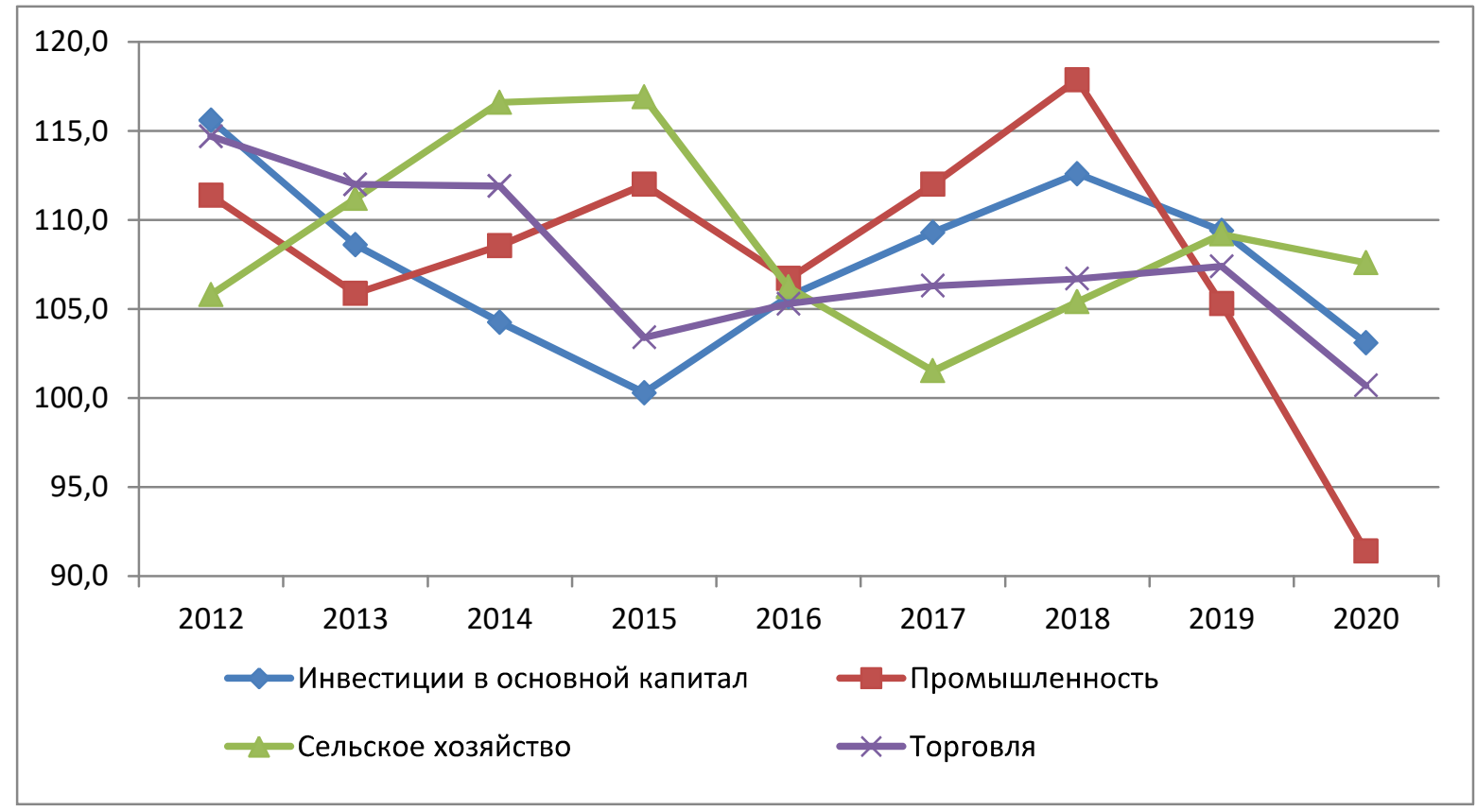

Рисунок 2 - Динамика отдельных показателей ЕАЭС в условной ЭССЕ (прочентов)

Следует отметить, что введение единой условной ЭССЕ не исключает необходимости использования в целях экономического анализа результатов международных сопоставлений ВВП. Так же, как и для Европейского Союза, несмотря на наличие общей валюты, сохраняется необходимость в использовании паритетов покупательной способности (ППС) евро к доллару США для проведения экономического анализа, так и для ЕАЭС необходимо будет определять ППС ЭССЕ к доллару США. 
По итогам развития предложенного нами подхода к представлению данных ЕАЭС в единой счетной единице нами была разработана методология условной ЭССЕ и расчета курсов и ППС национальных валют стран ЕАЭС и доллара США к ЭССЕ [12]. Вкратце ее содержание сводится к следующему.

Для определения условной ЭССЕ данные по ВВП стран ЕАЭС в национальных валютах $G_{t}$ представляются в долларах США по курсам $r_{t}$ и по ППС $e_{t}$ национальных валют к доллару США:

$$
G_{t}^{r}=G_{t} / r_{t} ; G_{t}^{e}=G_{t} / e_{t}
$$

Затем определяются средние индексы изменения объемов ВВП в долларах США по курсам и ППС национальных валют $I_{t}^{G^{r}}=G_{t}^{r} / G_{t-1}^{r}$ и $I_{t}^{G^{e}}=G_{t}^{e} / G_{t-1}^{e}$ и расщепляются на отношение средних индексов изменения ВВП стран ЕАЭС в национальных валю$\operatorname{tax}$ в текущих ценах $I_{t}^{G}$ и средних индексов изменения курсов/ППС национальных валют стран ЕАЭС к доллару США $I_{t}^{r}$ или $I_{t}^{e}$ :

$$
I_{t}^{G^{r}}=I_{t}^{G} / I_{t}^{r} ; \quad I_{t}^{G^{e}}=I_{t}^{G} / I_{t}^{e} .
$$

Такое расщепление индексов осуществляется в соответствии с теорией факторного индексного анализа, приведенной в ряде монографий и учебников по статистике [3-8]. При этом индексы количественных показателей (в нашем случае это различные объемные стоимостные показатели) принято рассчитывать по формуле Ласпейреса, используя в качестве соизмерителей качественные показатели (в нашем случае это курсы и ППС национальных валют к доллару США) для базисного периода. Индексы качественных показателей, наоборот, рассчитываются по формуле Пааше, когда в качестве соизмерителей используются количественные показатели, взятые для отчетного периода.

Следует иметь в виду, что средние индексы изменения ВВП ЕАЭС в национальных валютах в текущих ценах $I_{t}^{G}$, рассчитанные с использованием разных весов, могут расходиться. В учебниках по общей теории статистики рассматривается аналогичная ситуация, связанная с индексами цен, рассчитываемыми по формулам Пааше и Ласпейреса (то есть по весам базисного или отчетного периода) и приводится формула, оценивающая это расхождение, предложенная согласно разным источникам В.И. Борткевичем [6, с.543] и проф. Л.С. Казинцем [7, с.554], [8, с.355-356]. Мы рассмотрели эту ситуацию, рассчитывая средние индексы изменения ВВП стран ЕАЭС в национальных валютах в текущих ценах $I_{t}^{G}$, взвешенные по весам стран ЕАЭС в ВВП ЕАЭС, определенном по курсам и по ППС национальных валют к доллару США [9].

Для исключения этого расхождения предлагается использовать в обеих формулах индексы, рассчитанные по весам стран ЕАЭС в ВВП ЕАЭС в долларах США по ППС национальных валют к доллару США:

$$
I_{t}^{G}=\frac{\sum G_{t} / e_{t-1}}{\sum G_{t-1} / e_{t-1}}=\frac{\sum G_{t-1} / e_{t-1} \times \frac{G_{t}}{G_{t-1}}}{\sum G_{t-1} / e_{t-1}}=\sum w_{t-1}^{\epsilon} \times i_{t}^{G},
$$


где $w_{t-1}^{e}=\frac{G_{t-1} / e_{t-1}}{\sum G_{t-1} / e_{t-1}}-$ страновая структура ВВП ЕАЭС предыдущего периода в долларах США по ППС национальных валют к доллару США предыдущего периода;

$i_{t}^{G}=G_{t} / G_{t-1}-$ индексы роста объемов ВВП государств - членов ЕАЭС в национальных валютах в отчетном периоде.

Теперь можно рассчитать средние индексы изменения курсов и ППС национальных валют к доллару США:

$$
I_{t}^{r}=I_{t}^{G} / I_{t}^{G^{r}} ; \quad I_{t}^{e}=I_{t}^{G} / I_{t}^{G^{e}}
$$

Примем для базисного года «0» курс условной единиџы ЭССЕ к доллару США на уровне $N$ единиц условной ЭССЕ $=1$ доллар США $\left(R_{0}=N\right)$. А ППС условной единищы ЭССЕ к доллару США рассчитаем по формуле:

$$
E_{0}=R_{0} \times \frac{\sum G_{0}^{r}}{\sum G_{0}^{e}}
$$

Для последующих периодов расчетныле курсы и ППС ЭССЕ к доллару США определятся с использованием средних индексов изменения курсов и ППС национальных валют стран ЕАЭС к доллару США:

$$
R_{t}=R_{t-1} \times I_{t}^{r} ; \quad E_{t}=E_{t-1} \times I_{t}^{e} .
$$

С использованием этих курсов и ППС ЭССЕ к доллару США рассчитаем ВВП стран ЕАЭС в условной ЭССЕ:

$$
G_{t}^{R}=G_{t}^{r} \times R_{t} ; \quad G_{t}^{E}=G_{t}^{e} \times E_{t}
$$

Имея данные по ВВП стран ЕАЭС в национальной валюте и в ЭССЕ, можно определить расчетные курсы и ППС национальных валют к ЭССЕ:

$$
\rho_{t}=\frac{G_{t}}{G_{t}^{R}} ; \quad \varepsilon_{t}=\frac{G_{t}}{G_{t}^{E}}
$$

Результаты и анализ. Результаты расчетов курсов и ППС национальных валют стран ЕАЭС и доллара США к ЭССЕ на основе данных Евразийской экономической комиссии по статистике стран ЕАЭС [10] и Всемирного банка по ППС национальных валют стран ЕАЭС к доллару США [11] приведены в таблицах 1 и 2.

Теперь условную ЭССЕ можно применить в качестве единой счетной единицы для всех стоимостных показателей стран ЕАЭС, что позволит суммировать данные стран ЕАЭС и рассчитывать динамику показателей в целом по региональному объединению. В таблице 3 приведены объемы некоторых показателей ЕАЭС, представленные в единой ЭССЕ, динамика которых зависит только от изменения физических объемов и цен статистических показателей. 
Таблища 1

(за 1 ЭСCE)

Расчетные курсы начиональных валют стран ЕАЭС и доллара США к ЭССЕ

\begin{tabular}{|c|c|c|c|c|c|c|}
\hline & 2015 & 2016 & 2017 & 2018 & 2019 & 2020 \\
\hline Армянский драм & 477,918 & 420,072 & 477,951 & 446,440 & 427,004 & 391,480 \\
\hline Белорусский рубль & 1,593 & 1,739 & 1,913 & 1,883 & 1,858 & 1,945 \\
\hline Казахстанский тенге & 221,728 & 299,137 & 322,783 & 318,622 & 340,172 & 330,590 \\
\hline Кыргызстанский сом & 64,462 & 61,123 & 68,187 & 63,631 & 62,026 & 61,923 \\
\hline Российский рубль & 60,938 & 58,624 & 57,767 & 57,926 & 57,529 & 57,592 \\
\hline Доллар США & 1,000 & 0,874 & 0,990 & 0,924 & $\mathbf{0 , 8 8 9}$ & $\mathbf{0 , 8 0 1}$ \\
\hline
\end{tabular}

Таблииа 2

Расчетные ППС начиональных валют стран ЕАЭС и доллара США к ЭССЕ (за 1 ЭСCE)

\begin{tabular}{|l|r|r|r|r|r|r|}
\hline & \multicolumn{1}{|c|}{$\mathbf{2 0 1 5}$} & \multicolumn{1}{c|}{$\mathbf{2 0 1 6}$} & \multicolumn{1}{c|}{$\mathbf{2 0 1 7}$} & \multicolumn{1}{c|}{$\mathbf{2 0 1 8}$} & \multicolumn{1}{c|}{$\mathbf{2 0 1 9}$} & \multicolumn{1}{c|}{$\mathbf{2 0 2 0}$} \\
\hline Армянский драм & 443,532 & 399,393 & 382,573 & 373,177 & 358,650 & 354,388 \\
\hline Белорусский рубль & 1,347 & 1,397 & 1,494 & 1,590 & 1,636 & 1,746 \\
\hline Казахстанский тенге & 257,387 & 274,533 & 297,412 & 308,227 & 314,242 & 315,629 \\
\hline Кыргызстанский сом & 43,978 & 41,460 & 41,598 & 40,814 & 40,208 & 41,245 \\
\hline Российский рубль & 60,437 & 59,928 & 59,172 & 58,785 & 58,604 & 58,386 \\
\hline Доллар США & $\mathbf{2 , 5 6 5}$ & $\mathbf{2 , 4 7 7}$ & $\mathbf{2 , 4 5 3}$ & $\mathbf{2 , 3 8 4}$ & $\mathbf{2 , 2 9 8}$ & $\mathbf{2 , 2 5 6}$ \\
\hline
\end{tabular}

Как видно из таблицы, динамика показателей ЕАЭС, представленных в единой условной ЭССЕ, ровная, без резких колебаний, свойственных для рядов этих показателей, представленных в долларах США.

Из теории известно, что индексы стоимостных показателей $I_{t}^{s}$ разлагаются на произведение индексов физического объема $I_{t}^{q}$ и цен $I_{t}^{p}[3-8]$ :

$$
I_{t}^{s}=I_{t}^{q} \times I_{t}^{p}
$$

Данные в единой условной ЭССЕ представляют собой произведение физических объемов и цен. Поэтому их динамика также представляет произведение индексов физического объема $I_{t}^{q}$ и цен $I_{t}^{p}$. При этом, первый индекс рассчитывается по формуле Ласпейреса (поскольку является индексом количественного показателя), а второй - по формуле Пааше (поскольку является индексом качественного показателя), а сам индекс изменения стоимости представляет их произведение. Данные индексы являются соответственно средними индексами изменения физического объема, дефляторов и стоимостного показателя в национальных валютах стран ЕАЭС. 
На рисунках 3 и 4 приведены соответственно индексы физического объема и дефляторы отдельных показателей ЕАЭС, представленных в единой условной ЕАЭС (см. таблицу 3). Как видно из этих рисунков в 2015 году низкие ИФО компенсировались высокими величинами дефляторов, что выравнивало динамику стоимостных показателей в текущих ценах.

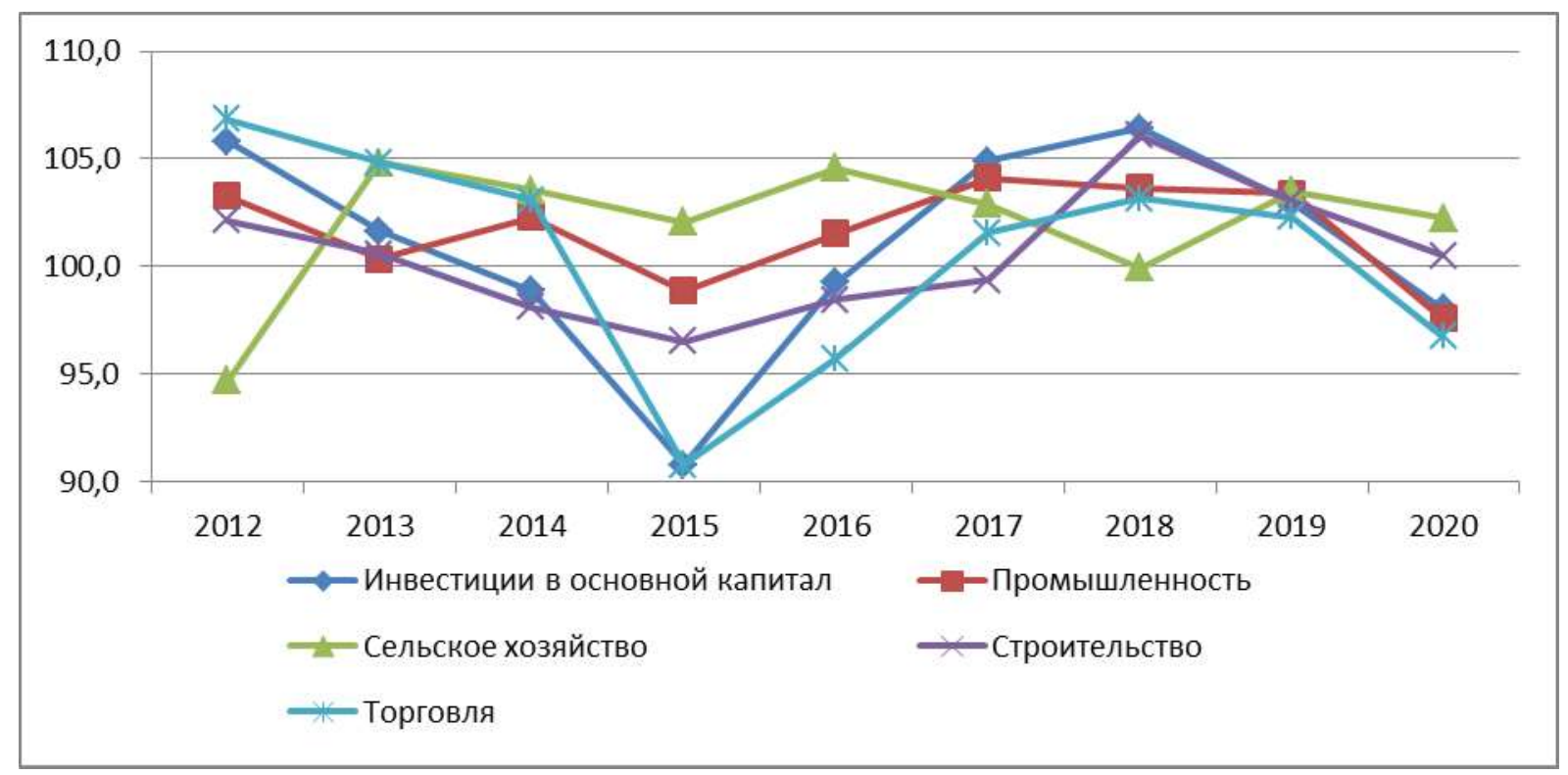

Рисунок 3 - ИФО отдельных показателей ЕАЭС, представленных в единой условной ЭССЕ (прочентов)

Таблища 3

Объемы отдельных показателей ЕАЭС, представленных в единой условной ЭССЕ (млн. ЭССЕ по курсам начиональных валют к ЭССЕ)

\begin{tabular}{|l|c|c|r|r|r|r|}
\hline & $\mathbf{2 0 1 5}$ & $\mathbf{2 0 1 6}$ & $\mathbf{2 0 1 7}$ & $\mathbf{2 0 1 8}$ & $\mathbf{2 0 1 9}$ & \multicolumn{1}{c|}{$\mathbf{2 0 2 0}$} \\
\hline Промышленность & 960962 & 1025774 & 1149095 & 1354298 & 1425433 & 1303382 \\
\hline Строительство & 135056 & 140191 & 148305 & 165574 & 179959 & 188200 \\
\hline Сельское хозяйство & 107203 & 113804 & 115487 & 121747 & 132934 & 143066 \\
\hline Торговля & 510466 & 537689 & 571336 & 609652 & 654631 & 659308 \\
\hline $\begin{array}{l}\text { Инвестиции в ос- } \\
\text { новной капитал }\end{array}$ & 275728 & 291482 & 318643 & 358696 & 392234 & 404546 \\
\hline
\end{tabular}

Поскольку условная ЭССЕ определена с учетом веса экономик стран, входящих в региональное объединение, на основе данных международных сопоставлений ВВП по ППС, то это позволяет иметь реальное представление не только о динамике экономического развития стран объединения, но и о страновой структуре экономики объединения. Объемы ВВП стран ЕАЭС и в целом по региональному объединению в единой условной ЭССЕ приведены в таблицах 4 и 5. Данные в таблице 4 характеризуют динамику ВВП по ЕАЭС в единой условной единице в текущих ценах, а данные в таблице 5 отражают реальный вес каждой страны в ВВП ЕАЭС. 


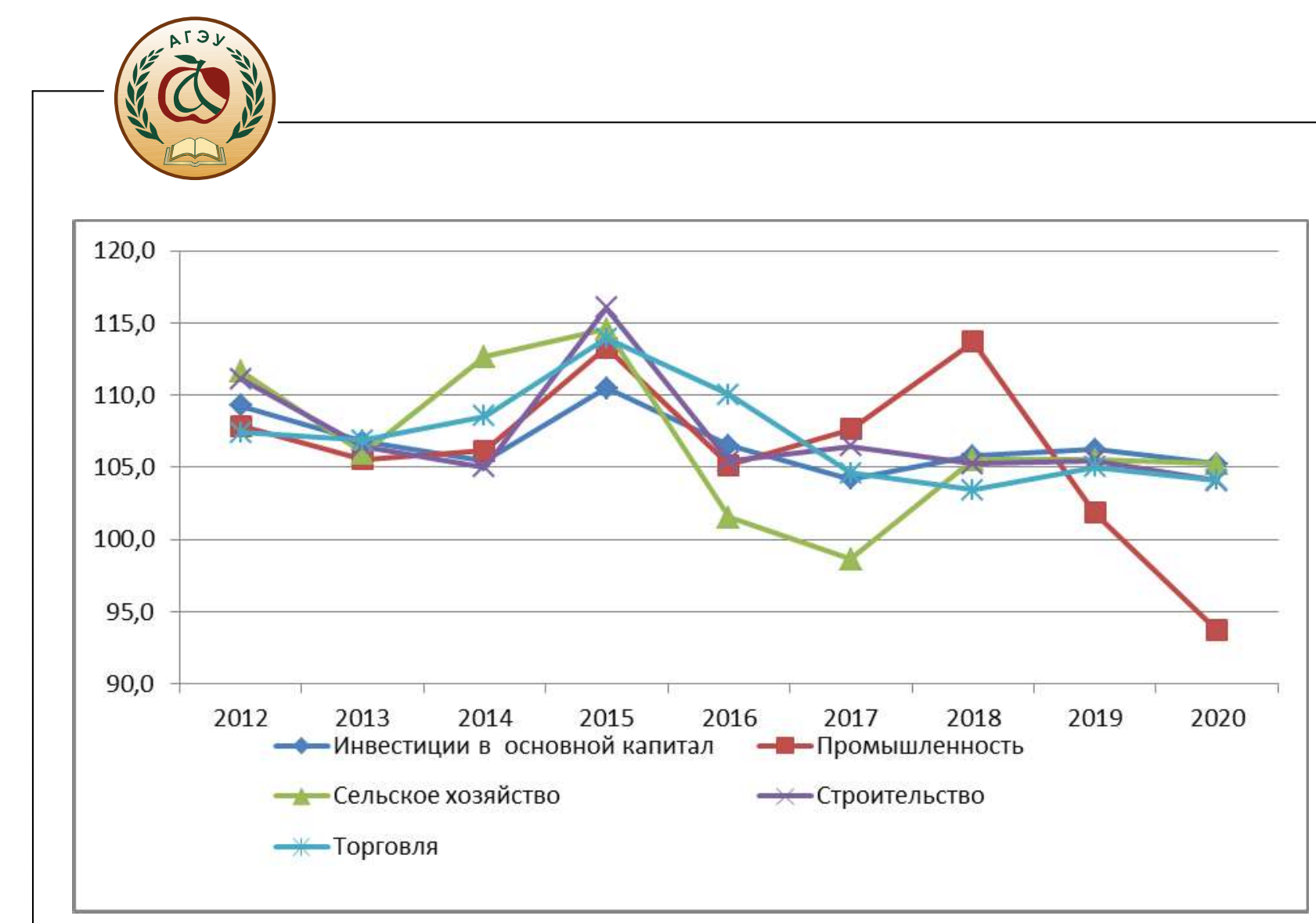

Рисунок 4 - Дефляторы отдельных показателей ЕАЭС, представленных в единой условной ЭССЕ (процентов)

Приведенные в таблицах 4 и 5 данные показывают одинаковые результаты для показателя ВВП регионального объединения, представленного в долларах США как по курсам, так и по ППС национальных валют к ЭССЕ. Если же сравнить данные по отдельным странам ЕАЭС, то можно увидеть, что они различаются. Причиной этого расхождения является то, что курсы и ППС национальных валют к ЭССЕ имеют различную динамику.

\section{Таблица 4}

Валовой внутренний продукт стран ЕАЭС (млрд. ЭССЕ по курсам начиональных валют к ЭССЕ)

\begin{tabular}{|l|r|r|r|r|r|r|}
\hline & \multicolumn{1}{|c|}{$\mathbf{2 0 1 5}$} & \multicolumn{1}{c|}{$\mathbf{2 0 1 6}$} & $\mathbf{2 0 1 7}$ & \multicolumn{1}{c|}{$\mathbf{2 0 1 8}$} & \multicolumn{1}{c|}{$\mathbf{2 0 1 9}$} & \multicolumn{1}{c|}{$\mathbf{2 0 2 0}$} \\
\hline Армения & 10,6 & 12,1 & 11,6 & 13,5 & 15,3 & 15,8 \\
\hline Беларусь & 56,5 & 54,6 & 55,3 & 64,9 & 72,7 & 75,6 \\
\hline Казахстан & 184,4 & 157,0 & 168,5 & 194,0 & 201,8 & 213,9 \\
\hline Кыргызстан & 6,7 & 7,8 & 7,8 & 8,9 & 10,0 & 9,7 \\
\hline Россия & 1363,5 & 1460,4 & 1589,9 & 1793,0 & 1898,9 & 1857,3 \\
\hline ЕАЭС & $\mathbf{1 6 2 1 , 6}$ & $\mathbf{1 6 9 1 , 9}$ & $\mathbf{1 ~ 8 3 3 , 1}$ & $\mathbf{2 ~ 0 7 4 , 4}$ & $\mathbf{2 ~ 1 9 8 , 7}$ & $\mathbf{2 ~ 1 7 2 , 2}$ \\
\hline
\end{tabular}


Таблица 5

Валовой внутренний продукт стран ЕАЭС (млрд. ЭССЕ по ППС национальных валют $\kappa$ ЭССЕ)

\begin{tabular}{|l|r|r|r|r|r|r|}
\hline & \multicolumn{1}{|c|}{$\mathbf{2 0 1 5}$} & \multicolumn{1}{c|}{$\mathbf{2 0 1 6}$} & \multicolumn{1}{c|}{$\mathbf{2 0 1 7}$} & \multicolumn{1}{c|}{$\mathbf{2 0 1 8}$} & \multicolumn{1}{c|}{$\mathbf{2 0 1 9}$} & \multicolumn{1}{c|}{$\mathbf{2 0 2 0}$} \\
\hline Армения & 11,4 & 12,7 & 14,5 & 16,1 & 18,2 & 17,4 \\
\hline Беларусь & 66,8 & 68,0 & 70,8 & 76,9 & 82,5 & 84,2 \\
\hline Казахстан & 158,8 & 171,1 & 182,8 & 200,6 & 218,4 & 224,0 \\
\hline Кыргызстан & 9,8 & 11,5 & 12,8 & 14,0 & 15,4 & 14,5 \\
\hline Россия & 1374,8 & 1428,7 & 1552,1 & 1766,8 & 1864,1 & 1832,1 \\
\hline ЕАЭС & $\mathbf{1 ~ 6 2 1 , 6}$ & $\mathbf{1 6 9 1 , 9}$ & $\mathbf{1 ~ 8 3 3 , 1}$ & $\mathbf{2 ~ 0 7 4 , 4}$ & $\mathbf{2 ~ 1 9 8 , 7}$ & $\mathbf{2 ~ 1 7 2 , 2}$ \\
\hline
\end{tabular}

Важным показателем международных сопоставлений является показатель уровня цен в данной стране по отношению к уровню цен в стране, валюта которой принята за единую. В международных сопоставлениях ВВП в качестве такой валюты принят доллар США. Уровень цен рассчитывается путем деления ППС к курсу национальных валют к доллару США. Результаты расчетов этого показателя для стран ЕАЭС приведены в таблице 6.

Таблий 6

Уровень цен в странах ЕАЭС по отночению к уровню чен в США (прочентов)

\begin{tabular}{|l|r|r|r|r|r|r|}
\hline & \multicolumn{1}{|c|}{$\mathbf{2 0 1 5}$} & \multicolumn{1}{c|}{$\mathbf{2 0 1 6}$} & \multicolumn{1}{c|}{$\mathbf{2 0 1 7}$} & \multicolumn{1}{c|}{$\mathbf{2 0 1 8}$} & \multicolumn{1}{c|}{$\mathbf{2 0 1 9}$} & \multicolumn{1}{c|}{$\mathbf{2 0 2 0}$} \\
\hline Армения & 36,2 & 33,6 & 32,3 & 32,4 & 32,5 & 32,1 \\
\hline Беларусь & 33,0 & 28,3 & 31,5 & 32,7 & 34,1 & 31,9 \\
\hline Казахстан & 45,3 & 32,4 & 37,2 & 37,5 & 35,7 & 33,9 \\
\hline Кыргызстан & 26,6 & 23,9 & 24,6 & 24,9 & 25,1 & 23,6 \\
\hline Россия & 38,7 & 36,1 & 41,3 & 39,4 & 39,4 & 36,0 \\
\hline $\begin{array}{l}\text { В среднем } \\
\text { по ЕАЭС }\end{array}$ & $\mathbf{3 9 , 0}$ & $\mathbf{3 5 , 3}$ & $\mathbf{4 0 , 4}$ & $\mathbf{3 8 , 8}$ & $\mathbf{3 8 , 7}$ & $\mathbf{3 5 , 5}$ \\
\hline
\end{tabular}

Полученные данные показывают заметное расхождение уровня цен между странами ЕАЭС. Так, если в Казахстане уровень цен в 2015 году составлял более 45\% по отношению к уровню цен в США, то в Кыргызстане только 26,6\%. То есть расхождение уровней цен составляло 1,7 раза. По ЕАЭС в целом уровень цен на самом низком уровне был в 2016 году (35,3\%). В 2017 году он вырос до 40,4\%, а затем к 2020 году вновь снизился (до 35,5\%). В 2020 году уровень цен по странам различался в 1,5 раза (36\% в России против 23,6\% в Кыргызстане).

В качестве базы сравнения можно принять уровень цен не в США, а средний по ЕАЭС уровень цен. Уровень цен в странах ЕАЭС по отношению к среднему по региональному объединению уровню цен можно определить путем деления данных по каждой строке таблицы 6 на данные последней строки (результаты приведены в таблице 7). 
Аналогичные результаты можно получить путем деления ППС на курсы национальных валют к единой условной ЭССЕ (из таблиц 1 и 2).

Как видно из таблицы 7, в России уровень цен практически весь рассматриваемый период (кроме 2015 года) превышал среднее по ЕАЭС значение (100\%). В Казахстане в 2015 году уровень цен $(116,1 \%)$ значительно превышал среднее по ЕАЭС значение, что связано с задержкой обесценения тенге до августа 2016 года. В последующие годы уровень цен в Казахстане находился в пределах 92-97\% от среднего по ЕАЭС значения. В Армении уровень цен после его некоторого повышения 2016 году резко снизился в следующем году, что связано с относительно небольшим обесценением национальной валюты к доллару США в сравнении с обесценением национальных валют других стран ЕАЭС в 2016 году и продолжающемся обесценении армянского драма при некотором укреплением валют других стран в 2017 году. В последующие годы уровень цен в Армении неуклонно рос. В Беларуси уровень цен после его снижения 2016-2017 года затем заметно вырос. В Кыргызстане наблюдалось менее заметное колебание уровня цен. Приведенные данные показывают, что уровни цен Казахстана и России находятся вблизи среднего по ЕАЭС значения (100\%), в Армении и Беларуси составляют примерно 90\%, а в Кыргызстане уровень цен находится на уровне примерно на треть ниже среднего по ЕАЭС значения.

Таблица 7

Уровень ценн в странах ЕАЭС по отношению к среднему по ЕАЭС уровню цен (прочентов)

\begin{tabular}{|l|r|r|r|r|r|r|}
\hline & \multicolumn{1}{|c|}{$\mathbf{2 0 1 5}$} & \multicolumn{1}{c|}{$\mathbf{2 0 1 6}$} & \multicolumn{1}{c|}{$\mathbf{2 0 1 7}$} & \multicolumn{1}{c|}{$\mathbf{2 0 1 8}$} & \multicolumn{1}{c|}{$\mathbf{2 0 1 9}$} & \multicolumn{1}{c|}{$\mathbf{2 0 2 0}$} \\
\hline Армения & 92,8 & 95,1 & 80,0 & 83,6 & 84,0 & 90,5 \\
\hline Беларусь & 84,6 & 80,3 & 78,1 & 84,4 & 88,1 & 89,8 \\
\hline Казахстан & 116,1 & 91,8 & 92,1 & 96,7 & 92,4 & 95,5 \\
\hline Кыргызстан & 68,2 & 67,8 & 61,0 & 64,1 & 64,8 & 66,6 \\
\hline Россия & 99,2 & 102,2 & 102,4 & 101,5 & 101,9 & 101,4 \\
\hline $\begin{array}{l}\text { В среднем } \\
\text { по ЕАЭС }\end{array}$ & $\mathbf{1 0 0 , 0}$ & $\mathbf{1 0 0 , 0}$ & $\mathbf{1 0 0 , 0}$ & $\mathbf{1 0 0 , 0}$ & $\mathbf{1 0 0 , 0}$ & $\mathbf{1 0 0 , 0}$ \\
\hline
\end{tabular}

Различие в уровне цен в странах регионального объединения указывает на то, что соответственно должны различаться и страновые ППС ЭССЕ к доллару США. Аналогичная ситуация наблюдается в еврозоне, где странам с низким уровнем цен соответствует более низкий паритет евро к доллару США, а для стран с высоким уровнем цен - более высокий паритет. На это в частности, указывает А.Е. Косарев: «Например, если во всех странах еврозоны официальный курс евро к доллару США, естественно, одинаков и в среднем за 2011 г. составил 0,72 евро за доллар США, то паритет евро и доллара в этих странах различается в зависимости от уровня экономического развития страны... Иными словами, если определенный набор товаров и услуг можно в США купить за 1 доллар, то эквивалентный набор товаров и услуг в 2011 г. можно было приобрести в Финляндии и Люксембурге за 91 евроцент, тогда как в Черногории для этого было бы достаточно израсходовать только 37 евроцентов - уровень цен в небогатой Черногории в два с половиной раза ниже, чем в Финляндии и Люксембурге» [12, с.70]. 
ППС ЭССЕ к доллару США для регионального объединения в целом представляет собой обратную величину ППС доллара США к ЭССЕ (приведен в таблице 2). Для расчета этого же показателя по странам ЕАЭС ППС ЭССЕ ЕАЭС к доллару США следует умножить на уровень цен из таблицы 7 (результаты расчетов приведены в таблице 8).

Полученные результаты показывают, что благодаря более низкому уроню цен в Кыргызстане покупательная способность ЭССЕ в этой стране в 2015 - 2020 годах была выше, чем в других странах ЕАЭС. В частности, в 2020 году ППС 1 доллара США в Кыргызстане составлял 30 ЭССЕ-центов. В то же время в России почти всегда необходимо было потратить больше единиц ЭССЕ за покупку товаров и услуг стоимостью 1 доллар США, в 2020 году для этого требовалось 45 ЭССЕ-центов. В Казахстане покупательная способность ЭССЕ почти всегда (кроме 2015 года) была выше средней по ЕАЭС. В 2020 году 1 доллар США в Казахстане был эквивалентен 42 ЭССЕ-центам. Средняя же величина по ЕАЭС ППС 1 доллара США составляла 44 ЭССЕ-цента.

Таблий 8

Расчетные ППС ЭССЕ к доллару США (единии ЭССЕ за 1 доллар США)

\begin{tabular}{|l|r|r|r|r|r|r|}
\hline & \multicolumn{1}{|c|}{$\mathbf{2 0 1 5}$} & \multicolumn{1}{c|}{$\mathbf{2 0 1 6}$} & \multicolumn{1}{c|}{$\mathbf{2 0 1 7}$} & $\mathbf{2 0 1 8}$ & $\mathbf{2 0 1 9}$ & \multicolumn{1}{c|}{$\mathbf{2 0 2 0}$} \\
\hline Армения & 0,36 & 0,38 & 0,33 & 0,35 & 0,37 & 0,40 \\
\hline Беларусь & 0,33 & 0,32 & 0,32 & 0,35 & 0,38 & 0,40 \\
\hline Казахстан & 0,45 & 0,37 & 0,38 & 0,41 & 0,40 & 0,42 \\
\hline Кыргызстан & 0,27 & 0,27 & 0,25 & 0,27 & 0,28 & 0,30 \\
\hline Россия & 0,39 & 0,41 & 0,42 & 0,43 & 0,44 & 0,45 \\
\hline ЕАЭС & $\mathbf{0 , 3 9}$ & $\mathbf{0 , 4 0}$ & $\mathbf{0 , 4 1}$ & $\mathbf{0 , 4 2}$ & $\mathbf{0 , 4 4}$ & $\mathbf{0 , 4 4}$ \\
\hline
\end{tabular}

Заключение. Таким образом, в основе нашего предложения лежит представление стоимостных статистических данных стран ЕАЭС в некоторой условной единице, которая бы исключала изменение курсов национальных валют к доллару США и играла роль единой экономико-статистической счетной единицы, то есть применялась бы в целях анализа экономического развития ЕАЭС.

Используя расчетные курсы и ППС национальных валют к ЭССЕ, можно представить в единой условной ЭССЕ стоимостные показатели стран ЕАЭС. При этом динамику показателей в условной ЭССЕ в целом для ЕАЭС можно разложить на произведение средневзвешенных индексов физического объема и дефляторов стоимостных показателей стран регионального объединения. Страновая же структура данных, представленная в ЭССЕ по ППС национальных валют, полностью совпадает со структурой этих данных, представленных в долларах США по ППС.

Следует отметить, что данные в ЭССЕ в целом по ЕАЭС, рассчитанные как по курсам, так и по ППС национальных валют, будут совпадать. По отдельным же странам ЕАЭС они будут расходиться, их отношение представляет уровень цен в стране к среднему по ЕАЭС уровню цен. Тем самым покупательная способность ЭССЕ по странам ЕАЭС различается аналогично покупательной стоимости евро в еврозоне ЕС.

Предложенный методологический подход позволяет приводить в сопоставимый вид данные стран регионального союза, которые не имеют общей валюты, и проводить анализ экономического развития с учетом результатов международных сопоставлений ВВП. 


\section{Список использованной литературы и источников данных:}

1. Шокаманов Ю.К, Демесинова А.А. Система индексов для анализа экономического развития региональных объединений стран, не имеющих общей валюты // Журнал «Учет, аудит, статистика». 2018. №1 - сc.197-204.

2. Шокаманов Ю.К, Демесинова А.А. Использование условной счетной единицы для анализа экономического развития региональных объединений стран, не имеющих общей валюты // Журнал «Учет, аудит, статистика». 2018. №2 - сс.191-196.

3. Адамов В.Е. Факторный индексный анализ (Методология и проблемы). - М.: Статистика, 1977. - 200 c.

4. Аллен Р. Экономические индексы. М.: Статистика, 1980. - 256 с.

5. Бакланов Г.И. Некоторые вопросы индексного метода. - М.: Статистика, 1972. $-72 \mathrm{c}$.

6. Елисеева И.И., Юзбашев М.М. Общая теория статистики: Учебник. 5-е изд, перераб. и доп. Москва: Финансы и статистика, 2004. - 656 с.

7. Ефимова М.Р., Петрова Е.В., Румянцев В.Н. Общая теория статистики. Учебник. 2-е изд., испр. и доп. М.: Инфра-М, 2010. - 416 с.

8. Теория статистики: учебник / Р.А. Шмойлова, В.Г. Минашкин, Н.А. Садовникова, Е.Б. Шувалова; под ред. Р.А. Шмойловой. - 5-е изд. - М.: Финансы и статистика, 2008. - 656 с.: ил.

9. Шокаманов Ю.К, Демесинова А.А. Расхождение индексов, взвешенных по разным весам // Научно-информационный журнал «Экономика и статистика». - Астана: Агентство Республики Казахстан по статистике, 2018. - № 1. - C.4-10.

10. [Elektronnyi resurs] Statistika EAES// URL: http://www.eurasiancommission.org/ru/act/integr_i_makroec/dep_stat/union_stat/Pages/defau 1t.aspx (data obrashcheniya: 4.07.2021)

11. [Elektronnyi resurs] Vsemirnyi Bank: paritety pokupatelnoi sposobnosti natsionalnykh valyut $\mathrm{k}$ dollaru SShA po VVP// URL: https://data.worldbank.org/indicator/PA.NUS.PPP?locations=AM-BY-KZ-KG-

RU\&name_desc=false (data obrashcheniya: 4.07.2021)

12. Косарев А.Е. Паритет покупательной способности национальных валют уникальный инструмент международных сопоставлений. - Вопросы статистики, 2014, № 5. C.63-72.

\section{Транслитерированный список литературы (References):}

1. Shokamanov Yu.K, Demesinova A.A. Sistema indeksov dlya analiza ekonomicheskogo razvitiya regionalnykh obedinenii stran, ne imeyushchikh obshchei valyuty // Zhurnal «Uchet, audit, statistika». 2018. №1 - ss.197-204.

2. Shokamanov Yu.K, Demesinova A.A. Ispolzovanie uslovnoi schetnoi edinitsy dlya analiza ekonomicheskogo razvitiya regionalnykh obedinenii stran, ne imeyushchikh obshchei valyuty // Zhurnal «Uchet, audit, statistika». 2018. №2 - ss.191-196.

3. Adamov V.E. Faktornyi indeksnyi analiz (Metodologiya i problemy). - M.: Statistika, 1977. $-200 \mathrm{~s}$.

4. Allen R. Ekonomicheskie indeksy. M.: Statistika, 1980. - $256 \mathrm{~s}$.

5. Baklanov G.I. Nekotorye voprosy indeksnogo metoda. - M.: Statistika, 1972. - 72 s.

6. Eliseeva I.I., Yuzbashev M.M. Obshchaya teoriya statistiki: Uchebnik. 5-e izd, pererab. i dop. Moskva: Finansy i statistika, 2004. - 656 s. 
7. Efimova M.R., Petrova E.V., Rumyantsev V.N. Obshchaya teoriya statistiki. Uchebnik. 2-e izd., ispr. i dop. M.: Infra-M, 2010. - 416 s.

8. Teoriya statistiki: uchebnik / R.A. Shmoilova, V.G. Minashkin, N.A. Sadovnikova, E.B. Shuvalova; pod red. R.A. Shmoilovoi. - 5-e izd. - M.: Finansy i statistika, 2008. - 656 s.: il.

9. Shokamanov Yu.K, Demesinova A.A. Raskhozhdenie indeksov, vzveshennykh po raznym vesam // Nauchno-informatsionnyi zhurnal «Ekonomika i statistika». - Astana: Agentstvo Respubliki Kazakhstan po statistike, 2018. - № 1. - S.4-10.

10. [Elektronnyi resurs] Statistika EAES// URL: http://www.eurasiancommission.org/ru/act/integr_i_makroec/dep_stat/union_stat/Pages/defau lt.aspx (data obrashcheniya: 4.07.2021)

11. [Elektronnyi resurs] Vsemirnyi Bank: paritety pokupatelnoi sposobnosti natsionalnykh valyut $\mathrm{k}$ dollaru SShA po VVP// URL: https://data.worldbank.org/indicator/PA.NUS.PPP?locations=AM-BY-KZ-KG-

RU\&name_desc $=$ false (data obrashcheniya: 4.07.2021)

12. Kosarev A.E. Paritet pokupatelnoi sposobnosti natsionalnykh valyut - unikalnyi instrument mezhdunarodnykh sopostavlenii. - Voprosy statistiki, 2014, № 5. S.63-72.

\title{
БІРЫНҒАЙ ЭКОНОМИКАЛЫҚ-СТАТИСТИКАЛЫҚ ЕСЕП БІРЛІГІНДЕ ЕАЭО ЕЛДЕРІНІН ҚҰНДЫҚ СТАТИСТИКАЛЫҚ ДЕРЕКТЕРДІ КӨРСЕТУ ТУРАЛЫ
}

\author{
Ю.К. Шоқаманов*, А. Ә. Демесинова \\ Мемлекеттік басқару академиясы, Нұр-Сұлтан, Қазақстан \\ e-mail: shokamanov53@mail.ru
}

Түйін. Мақалада Еуразиялық экономикалық одақтың (ЕАЭО) экономикалық дамуын шартты экономикалық-статистикалық есеп бірлігін (ЭСЕБ) құолдану арққыльь талдаудың ддіснамалық тәсілі көрсетілген. АҚШ долларына қатысты ЭСЕБ-нің есептелген бавамы, АҚШ долларына құатысты ұлттық валюталардыцц САҚП арқыльы анықтаван, аймақ экономикасындавы елдердің салмавын ескере отырып ұлттық валюталардың АҚШ долларына багамдарының ортама өлшенген өзгеруіне ұқссас өзгередi.

Белгілі бір базистік жыл үшін ЭСЕБ-нің АҚШ долларына құатынасын (ставкасын) ескере отырып, осы кезеңдегі ұлттық валюталардың ЭСЕБ-не бавамын есептеу оңай. Келесі кезеңдерде АҚШ долларына қатысты ЭСЕБ бавамы ұлттық валюталардың АҚШ долларына қатысты бавамдарының өзгеруінің орташа өлшенген динамикасын есептелгенін ескере отырып анықталады. Осы негізде ұлттық валюталардың ЭСЕБ-не есептелген бавамдары да анықталады.

Сонымен қатар АҚШ долларына қатысты ЭСЕБ-нің САҚП есептеледі. Олар АҚШ долларына ЭСЕБ бавамдары, АҚШ долларына ұлттық валюталар бавамдар мен САҚП бойынша АҚШ долларында ұсынылван ЕАЭО елдерінің ЖІӨ-нің қатынасқа көбейту арқыль есептеледі. ЕАЭО елдерінің ұлттық валютада есептелген ЖІӨ-нін ЭСЕБ-не қатынасы, ұлттыьқ валюталардың САҚП-нің ЭСЕБ-не қатынасты білдіреді.

Түйінді сөздер: индексті талдау, жалпы валюта, шартты экономикалықстатистикалық есеп бірлігі, сатып алу қабілеттілігінің паритеті. 


\title{
ON THE PRESENTATION OF VALUE STATISTICAL DATA OF THE EAEU COUNTRIES IN THE UNIFIED ECONOMIC AND STATISTICAL ACCOUNT UNIT \\ Yu.K. Shokamanov*, A.A. Demesinova \\ Academy of Public Administration, Nur-Sultan, Kazakhstan \\ e-mail: shokamanov53@mail.ru
}

Summary. The article presents a methodological approach to the analysis of the economic development of the Eurasian Economic Union (EAEU) using a conditional economic and statistical unit of account (ESSE). The calculated rate of the ESSE against the US dollar changes in the same way as the weighted average change in national currencies against the US dollar, taking into account the weight of countries in the region's economy, determined by the PPP of national currencies against the US dollar.

Having taken for a certain base year a certain ratio (exchange rate) of the ESSE to the US dollar, it is not difficult to calculate the exchange rates of national currencies to the ESSE for this period. For subsequent periods, the rate of the ESSE against the US dollar is determined taking into account the calculated average weighted dynamics of changes in the exchange rates of national currencies against the US dollar. And on this basis the estimated exchange rates of national currencies against the ESSE are also determined.

The ESSE PPPs to the US dollar are also calculated, which are determined by producing ESSE rates against the US dollar at the ratio of the EAEU countries' GDP, presented in US dollars at exchange rates and PPPS of national currencies to the US dollar. The ratio of the GDP of EAEU countries in national currencies and the ESSE represents the PPP of national currencies to the ESSE.

Key words: index analysis, common currency, conditional economic-statistical unit of account, purchasing power parity.

\section{МРНТИ 05.11.65 \\ УДК 314(470+571)}

https://doi.org/10.51579/1563-2415.2021-3.09

\section{ФАКТОРЫ И ПЕРСПЕКТИВЫ ПРЕОДОЛЕНИЯ СОЦИОДЕМОГРАФИЧЕСКОГО КРИЗИСА В РОССИИ}

\author{
Яковец Т.Ю. \\ Международный институт П. Сорокина - Н. Кондратьева, Москва, Россия \\ e-mail: tzag@mail.ru
}

\begin{abstract}
Аннотация. Цель статьи состоит в исследовании основньх факторов, позволяюших преодолеть настоящий этап сочиодемографического кризиса в России и оченке перспектив этого процесса с учетом динамики демографического развития страны. Методология исследования строится на использовании комплексного подхода к исследованию сочиодемографического положения страны, предпологаючего проведение системного анализа демографических прочессов во взаимосвязи с сочиальными и экономическими процессами.

В статье проведен анализ демографических, экономических, государственнополитических факторов, влияющих на сочиодемографический кризис в России. Кроме
\end{abstract}

